\title{
Chronic Desires and Crippling Cruelty in Sarah Kane’s Blasted
}

\author{
Eugene Ngezem \\ Clayton State University
}

Sarah Kane's Blasted (1995), set in Leeds, a war-ravaged city in England, mirrors the ruins of contemporary cities, and presents depraved characters who leave indelible prints of ruin as they have sex with impunity, torture at ease, and murder at whim. Hanging on the skin of their own obsessive lust, depression, depravation, and cruelty, Kane's characters display spiteful conduct and protracted cravings. The play depicts a world of sex maniacs, of acute pain, and of cannibalism. Set in a "very expensive hotel room in Leeds (England)-the kind that is so expensive it could be anywhere in the world" (Kane 3), the playwright presents a tabloid journalist, Ian, and a Soldier, who both have severe and violent sexual drives, a young lady who is an innocent victim of sexual violence, a child whose corpse is eaten, and citizens massacred with utmost brutality.

Blasted, considered to be too vile for the stage, starts with Ian talking about his stench and that of the city, and "coughing terribly in the bathroom. He spits in the sink..." (4), suggesting, as it were, the continuous erosion of values that define human dignity. He is sick of excessive consumption of alcohol, cigarettes, and, maybe, evil, yet he is obstinately glued to sex and viciousness till his death. He chooses dark pleasure over a healthy, fulfilling life. His language, tone, and acts speak to a depraved man who converts a hotel room to fortress of greed and evil, and suddenly becomes a victim in a baneful world he perpetuates. Kane's Ian uses "fuck," an obscene, disdainful word frequently in the play. His obscenities lead him to real sexual acts often in the play, as he tells Cate, "I'm fucked" (11). He quickly and sexually engages a reluctant Cate, who is far younger than him: “He kisses her. She pulls away and wipes her mouth” while telling him, “Don’t put your tongue in, I don’t like it” (12). Ian continues to molest Cate and to masturbate: "Ian kisses her... He puts his hand under her top and moves it towards her breast. With the other hand he undoes his trousers and starts masturbating. He begins to undo her top. She pushes him away” (14), as he tells her, "If I don’t come my cock aches” (15).

Notwithstanding Cate's resistance, we are told that "apparently still in pain, (Ian) takes her hand and grasps it around his penis, keeping his own hand over the top. Like this, he masturbates until he comes with some genuine pain" (15). After kissing Cate passionately, Ian turns his back and Cate once more "wipes her mouth" (17), signaling an unrequited, forced love, and, of course, a violation of the privacy of her lips. As a partaker in a world of sex maniacs, Ian asks Cate, "You ever had a fuck with a woman" (19), and later forces her on her back, "lies between her legs, and simulates sex. As he comes, Cate sits bolt upright with a shout" (27), as Ian locks the door to prevent her from leaving. In a violent, nonchalant manner, Ian uses Cate as his sex object and pleasure, and does so without taking into account the physical and psychological pain she endures. Cate is Ian's sex prisoner whose liberty is stripped and her dignity crushed.

Eugene Ngezem, Ph.D., associate professor, Department of English, Clayton State University, USA; main research field: English Literature. 
Notwithstanding the asexual nature of Cate, she is lured into Ian's sexual frenzy as she "sucks his nipples," "undoes his trousers," "begins to perform oral sex on (him)," "bites his penis as hard as she can," and his "cry of pleasure turns into pain" as Ian "tries to pull away but Cate holds on with her teeth" (30-31). In a world, where violence is everywhere evident and seems to be the only route in a brutal city, Cate bites Ian in revenge. After biting Ian, Cate complains that she was hurting, and becomes disgusted after noticing Ian's blood and pubic hair in her mouth. Ian, however, insists that his penis "went down on Stella all the time, didn't hurt her" (32), suggesting, as it were, a contemporary world where many like Ian have multiple sex partners. Sex produces grave pain and blood: Cate complains, “I can’t piss. It’s just blood” (34).

The intrusion of Soldier takes the sexual madness, violence, and cruelty to an acute level. As soon as he enters the hotel room, he states "I can smell the sex," "closes his eyes and rubs 'Cates knickers' gently over his face, smelling with pleasure” (37). As a premonition to the sexual hurricane and death in the play, a mortal bomb blasts a huge hole in the hotel room and Soldier tells Ian "I am dying to make love" and boasts of the pain he and his fellow soldiers committed outside of town: "They held the men while I fucked the women. Youngest was twelve. Didn't cry, just lay there. Turned her over and-Then she cried. Made her lick me clean... Shot her father in the mouth. Brothers shouted. Hung them from the Ceiling by their testicles” (43). Like Sarah Kane who died by hanging herself by her shoe laces in a bathroom at London's College Hospital in 1999, Soldier kills his victims by hanging them. Soldier further boasts of stabbing a woman between her legs, on the fifth stab snapped her spine (46). Hanging men by their testicles and stabbing women between the legs point to cruelty and to excessive focus on the genitals, thus signaling a world glued to matters of sex and to fiendish attitude.

As Soldier asks Ian, "You never fucked a man before you killed him?” (47), Ian reads from the newspaper, "Kinky car dealer Richard Morris drove two teenage prostitutes into the country, tied them naked to fences and whipped them with belt before having sex" (48) and reports of priests and teachers who rape and shoot kids (48). After reading the stories and as a premonition to the brutal sexual experience and the maiming Soldier will inflict on Ian, Soldier tells Ian I am "going to fuck you" and inquires if Ian prefers to "be shot than fucked and shot” (49). Without hesitation or empathy, Soldier "holds the revolver to Ian's head... Pulls down Ian's trousers, undoes his own and rapes him-eyes closed and smelling Ian's hair... pulls up his trousers and pushes the revolver up Ian's anus” (49). After this coerced penetration of the vulva, using a penis and his revolver, he asks Ian, “you never fucked by a man before?” (49) as he brags of a young girl he "fucked” while telling Ian “don't think your Welsh arse is different to any other arse I fucked” (50). Soldier ends up sucking out Ians' eye balls and eating them and Ian exhumes and eats a dead baby and masturbates even when he is blind and about to die, yelling "cunt cunt cunt cunt cunt cunt cunt cunt cunt cunt cunt" (59). Characters are too addicted to desires to the extent that they consume anything and everything, even when they are maimed and dying.

As the foregoing discussion and preponderant of evidence have demonstrated, one would safely insist that while Sarah Kane's Blasted may be viewed as revolting, perceived as too extreme, and abhorred by some, it depicts, as it is the case in our current society, a world in avid sexual desires and maliciousness. The playwright show, in unambiguous terms and with telling finality, a world redden in chronic desires and extreme cruelty, a world sex is not only violent, but casual. In an article entitled, "Casual sexual relationships: Identifying definitions for one nightstands, booty calls, fuck buddies, and friends with benefits,” Jocelyn J. Wentland and Elke Reissing argue that "casual sexual relationships (CSRs) are common forms of sexual encounters among young adults" (167-77). Like a hurricane which tears everything on its path and leaves a pile of rubbish, the 
characters of Kane sexually bruise each other, leaving behind pain, blood, and death as they consume or tear everything on their path to insatiability.

\section{Works Cited}

Kane, Sarah. Blasted \& Phaedra's Love. London: Methuen, 1995.

Ompad, C. Danielle, et al. "Men Who Purchase Sex, Who Are They? An Interurban Comparison.” Journal of Urban Health: Bulletin of the New York Academy of Medicine (J Urban Health) 90.6 (2013): 1166-80.

Swager, Roger. "Evolution and Applications of the Term Consumerism: Theme and Variations.” The Journal of Consumer Affairs 28.2 (1994): 347-60.

Varman, Rohit and Russell W. Belk. “Consuming Postcolonial Shopping Malls.” Journal of Marketing Management 28.1-2 (2012): 62-84.

Wentland, Jocelyn J. and Reissing Elke. "Casual Sexual Relationships: Identifying Definitions for One Nightstands, Booty Calls, Fuck Buddies, and Friends with Benefits.” Canadian Journal of Human Sexuality 23.3 (2014): 167-77. 